\title{
Complexities and Uncertainties in Transitioning Small-Scale Coral Reef Fisheries
}

\author{
Pierre Leenhardt ${ }^{1,2}$, Matthew Lauer ${ }^{3}$, Rakamaly Madi Moussa ${ }^{1,2}$, Sally J. Holbrook ${ }^{4,5}$, \\ Andrew Rassweiler ${ }^{5,6}$, Russell J. Schmitt ${ }^{4,5}$ and Joachim Claudet ${ }^{1,2 *}$ \\ ' National Center for Scientific Research, Centre de Recherches Insulaires et Observatoire de l'Environnement (CRIOBE), USR \\ 3278 Centre National de la Recherche Scientifique-EPHE-UPVD, Perpignan, France, ${ }^{2}$ Laboratoire d'Excellence CORAIL, \\ Perpignan, France, ${ }^{3}$ Department of Anthropology, San Diego State University, San Diego, CA, USA, ${ }^{4}$ Department of Ecology, \\ Evolution, and Marine Biology, University of California, Santa Barbara, CA, USA, ${ }^{5}$ Marine Science Institute, University of \\ California, Santa Barbara, CA, USA, ${ }^{6}$ Department of Biological Science, Florida State University, Tallahassee, FL, USA
}

\section{OPEN ACCESS}

Edited by:

Wen-Cheng Wang,

National Taiwan Normal University,

Taiwan

Reviewed by:

John A. Cigliano,

Cedar Crest College, USA

Simon Foale,

James Cook University, Australia

*Correspondence:

Joachim Claudet

joachim.claudet@gmail.com

Specialty section:

This article was submitted to Marine Conservation and

Sustainability,

a section of the journal Frontiers in Marine Science

Received: 04 February 2016 Accepted: 25 April 2016 Published: 13 May 2016

Citation:

Leenhardt P, Lauer M, Madi

Moussa R, Holbrook SJ, Rassweiler A, Schmitt RJ and Claudet J (2016) Complexities and Uncertainties in Transitioning Small-Scale Coral Reef

Fisheries. Front. Mar. Sci. 3:70. doi: 10.3389/fmars.2016.00070
Coral reef fisheries support the development of local and national economies and are the basis of important cultural practices and worldviews. Transitioning economies, human development, and environmental stress can harm this livelihood. Here we focus on a transitioning social-ecological system as a case study (Moorea, French Polynesia). We review fishing practices and three decades of effort and landing estimates with the broader goal of informing management. Fishery activities in Moorea are quite challenging to quantify because of the diversity of gears used, the lack of centralized access points or markets, the high participation rates of the population in the fishery, and the overlapping cultural and economic motivations to catch fish. Compounding this challenging diversity, we lack a basic understanding of the complex interplay between the cultural, subsistence, and commercial use of Moorea's reefs. In Moorea, we found an order of magnitude gap between estimates of fishery yield produced by catch monitoring methods $\left(\sim 2 \mathrm{t} \mathrm{km}^{-2}\right.$ year $\left.{ }^{-1}\right)$ and estimates produced using consumption or participatory socioeconomic consumer surveys $\left(\sim 24 \mathrm{t} \mathrm{km}^{-2}\right.$ year $\left.{ }^{-1}\right)$. Several lines of evidence suggest reef resources may be overexploited and stakeholders have a diversity of opinions as to whether trends in the stocks are a cause for concern. The reefs, however, remain ecologically resilient. The relative health of the reef is striking given the socio-economic context. Moorea has a relatively high population density, a modern economic system linked into global flows of trade and travel, and the fishery has little remaining traditional or customary management. Other islands in the Pacific in similar contexts in Polynesia such as Hawaii, that continue to develop economically, may have small-scale fisheries that increasingly resemble Moorea. Therefore, understanding Moorea's reef fisheries may provide insight into their future.

Keywords: social-ecological systems, small-scale fisheries, coral reef fisheries, transitioning economy, catch monitoring, fishery yield, complexity, resilience 


\section{INTRODUCTION}

Coral reef fisheries are vital to millions of people dwelling along the world's coasts (Johnson et al., 2013; Teh et al., 2013; Cinner, 2014). They support the development of local and national economies by providing food, income, and employment, and also are the basis of important cultural practices and identities. Yet the coral reefs upon which these fisheries depend are some of the globe's most threatened coastal systems (Mumby and Steneck, 2008). Until recently, coral reefs worldwide demonstrated the capacity to return to coral dominance following perturbations that cause landscape-scale loss of coral, such as cyclones and bleaching (Jackson, 1992; Pandolfi and Jackson, 2006). In the past two decades, however, a growing number of studies have documented cases where major perturbations cause long-lasting and potentially irreversible ecosystem shifts, one of the most common being a shift from a coral-dominated to a macroalgaedominated state (Hughes, 1994; Shulman and Robertson, 1996; Hobbs et al., 2006; Rogers and Miller, 2006; Bruno et al., 2009). The dynamics of these state shifts are fundamental to understanding long-term sustainability of coral reefs and the fisheries that depend on them, yet the interacting human and ecological dynamics, including fisheries, that underpin coral reef resilience are poorly understood (Hughes et al., 2003, 2005, 2010).

Most coral reef fisheries are small-scale fisheries in that they involve simple technologies and are either subsistencebased, or supply small local markets, or roadside sellers. Despite their limited technological and economic scope, small-scale fisheries have been identified as a primary threat to coral reefs (Newton et al., 2007). Some studies suggest small-scale coral reef fisheries are experiencing declining fish biomass and size (Cinner J. E. et al., 2009) but the extent, magnitude, and variability of overexploitation is generally not well-documented (Jacquet and Pauly, 2008), and even the number of people involved in such fishing is poorly known (Teh et al., 2013). This paucity of understanding and uncertainty is attributable to the inherent complexity of small-scale coral reef fisheries. They evolve within locally specific social and ecological conditions, making them highly diverse. Variability arises from the diverse set of technologies used for harvesting marine resources, multiple overlapping social, economic, and cultural motivations for fishing, heterogeneous modes of governance, varied stakeholder organization, and complex interactions with other marine-use sectors and governance structures.

Here we explore the complexity of coral reef fisheries using Moorea, French Polynesia, as an example. Moorea presents an interesting case study in that economic development and intense exposure to globalization have not undermined the capacity of its coral reefs to recover from perturbations. Extensive, longterm ecological research on Moorea suggests that its reefs are quite resilient to disturbances (Done et al., 1991; Adjeroud et al., 2009; Adam et al., 2011, 2014; Trapon et al., 2011; Lamy et al., 2015, 2016; Galzin et al., 2016). Many Pacific islands have shown declines in the critical adaptive capacities that underpin resilience to environmental variability when they are more exposed to the pressures of globalization and global markets, have higher population densities, and widespread coastal development
(Pauly and Chua, 1988; Brewer et al., 2012). Interestingly, Moorea enjoys a higher standard of living than most Pacific islands while its reefs have demonstrated high resilience to environmental perturbation. This may suggest that higher levels of socioeconomic development may reduce dependence on coral reefs and associated human impact (Cinner J. et al., 2009) or may reflect other social or ecological characteristics of the system.

We describe Moorea's small-scale coral reef fishery by documenting fishing practices and reviewing uncertainties associated with estimates of effort and landings over the last three decades. Fishing activities on Moorea are widely dispersed, both spatially around the island and temporally throughout the day and the night, making the collection of accurate catch data challenging. Existing statistical data provided by the Territorial government cannot be used for this purpose because they do not effectively assess non-commercial fishing, the most widespread fishing practice on the island. Moreover, we lack a basic understanding of the complex interplay between the cultural, subsistence, and commercial use of Moorea's reefs. Filling these gaps in our knowledge of Moorea's fishery will help enhance the development of marine resource management initiatives that seek long-term sustainability of reef fisheries and foster ecosystem resilience.

\section{THE SOCIAL-ECOLOGICAL CONTEXT}

The island of Moorea is surrounded by a barrier reef, broken by 11 passes, enclosing a $49 \mathrm{~km}^{2}$ lagoon, whose width varies from 500 to $1500 \mathrm{~m}$, with depths of $0.5-30 \mathrm{~m}$ (Bell and Galzin, 1984). The island has a marine spatial management plan (Plan de Gestion de l'Espace Maritime, PGEM) initiated in 2004, the first in French Polynesia. The PGEM has four objectives: (1) rational use of resources and sustainable development; (2) managing conflicts for space in the lagoon; (3) controlling pollution and physical damage to marine environments; and (4) protecting marine ecosystems and endangered species. Although the PGEM was carefully developed over a 10 year consultation process, certain segments of the fishing community voiced opposition when it was implemented in 2004 (Aubanel et al., 2013), and it continues to be a source of tension and controversy (Walker, 2001; Gaspar and Bambridge, 2008; Walker and Robinson, 2009).

The uses of Moorea's coral reefs have fundamentally changed over the last 100 years. Moorea gradually transitioned during the late nineteenth century from a subsistence economy based on small-scale gardening and fishing to an economy that by the 1940s was based on cash cropping of vanilla and copra. In the 1960s, French military activities drove a burgeoning economy and employment opportunities that drew migrants from other parts of French Polynesia to the capital city, Papeete (Henningham, 1992; Salvat and Pailhe, 2002). These economic changes in French Polynesia influenced Moorea's social-ecological system in several important ways. With regular ferry service established between Moorea and Tahiti, residents of Moorea were able to commute to jobs in Papeete. Moreover, many Papeete residents moved to nearby Moorea or visit the island on weekends and occasionally fish there. Most notably, 
however, was rapid growth in tourism that progressively became the mainstay of Moorea's economy. In 2011, Moorea was the most visited island in French Polynesia with over 70,000 tourists visiting the island's 22 major hotels and 48 smaller "pensions de famille" (ISPF, 2001). The transition to a tourism-led economy has sustained a level of economic prosperity in French Polynesia, and it continues to be one of the wealthiest Pacific Island nations with a USD 15,272 per capita GDP (Baudchon et al., 2008). An economy that was once dominated by small-scale food production and subsistence fishing was replaced with tourism and service sectors as well as some export-oriented nonindigenous agriculture, such as pineapple. In addition, fishing became just one of many marine-focused activities that include scuba diving and beach and boating activities, each exerting different pressures on the coral reefs and lagoon ecosystem.

One important outcome of these transformations was very high population growth, a portion of which was due to immigration from other islands. Census figures indicate that Moorea's population grew from 5058 to 16,893 between 1971 and 2012 (ISPF, 2013) - an annual growth rate of $2.39 \%$, which is higher than the rate for French Polynesia as a whole $(1.57 \%)$. The effect these demographic changes have had on Moorea's fishery is unknown, but throughout the region fishing pressure appears to be linked to the number of local inhabitants although the relationship is poorly understood (Russ and Alcala, 1989; Jennings and Kaiser, 1998).

\section{FISHING CATEGORIES}

Fishing has formed the backbone of Polynesian societies since their initial colonization of the region (Oliver, 1974) and continues to be an integral part of the subsistence economy and Polynesian identity. Today, Moorea's coral reefs directly support two fundamental livelihoods on the island: fishing and tourism. In strict economic terms fishing-based incomes are dwarfed by tourism-based incomes, which stem mostly from tourist accommodations and reef-based recreational activities. A recent economic assessment estimated that recreational activities stemming from Moorea's reefs provided approximately 27 $\mathrm{M} € /$ year while fishing activities provided $4 \mathrm{M} € /$ year including 2.8 $\mathrm{M} €$ value placed on fish not sold but consumed within the fisher's household (Pascal and LePort, 2015). These figures, however, do not capture recreational fishing activities nor the high cultural value of reef fishing in Polynesian society (e.g., enjoyment, identity, prestige, worldview; Cinner, 2014).

Polynesian fishing activities can be lumped roughly into three categories: oceanic fisheries, coastal fisheries, and reef (or lagoon) fisheries. Reef fisheries are described as all activities involved in exploiting biological resources and carried out on the fringing and barrier reefs, channels, passes and hoa (small passes not always connected to the ocean) and down to the limits of coral growth (80-100 m depth; Galzin et al., 1989). According to Yonger (2002), Brenier (2009), and Leenhardt (2009) and our own observations, fishing is ubiquitous on Moorea with three broad categories of fishers: commercial fishers, subsistence fishers, and recreational fishers (Table 1). The latter term encompasses fishers not motivated by market imperatives or hunger, but cultural factors. The fisher population is composed of $69 \%$ recreational, $20 \%$ subsistence, and $11 \%$ commercial fishers but the categories are not mutually exclusive (Leenhardt, 2009; Brenier et al., 2014). Over half of the adult population fishes, with the vast majority of households having at least one person who fishes. While subsistence fishers are all Moorea residents, a certain number of commercial and recreational fishers come from the nearby Society Islands, mainly Tahiti (Leenhardt, 2009). It should be noted that nearly $70 \%$ of the people who fish on Moorea are recreational fishers, yet none of the catches from this category of fisher appear in the fisheries data collected in market surveys (Figure 1). Moreover, recreational fishing may account for $58 \%$ of the catches in the lagoon (Yonger, 2002), yet, a percentage of those catches are never recorded because they are directly destined for home consumption or shared among family or other community members. In addition, roadside sellers reported keeping a very small part of their catch on average for household consumption.

\section{CAUGHT SPECIES}

A diverse suite of species is targeted by fishing in Moorea's reefs. More than 40 genera of fishes can be found sold by the roadside. Three groups are caught most frequently: Iihi (soldierfish, Myripristis spp.), Paati (parrotfish, mixed species smaller than $50 \mathrm{~cm}$; mostly Scarus spp. and Chlorurus spp.), and Ume (unicornfish, Naso spp.; Table 2).

\section{FISHING GEAR TYPES}

The wide diversity of species caught in part reflects the many fishing techniques that are employed, each adapted to specific suites of organisms. Given the many different techniques, individual fishers often use a multifaceted approach, using several techniques depending on their preferences and resources, on the frequency of fishing, season, weather conditions, target species, and time of day. The main gear types used in the lagoon are spear guns, lines (handlines, hook-and-line), nets (gillnets or nets with pot traps), harpoons, beach seines, and trolling (Yonger, 2002; Leenhardt, 2009; Brenier et al., 2014). Although a wide variety of fishing methods are used, spearfishing dominates the (commercial) roadside catch: sellers reported that a large majority of biomass had been taken by spear gun with the remainder split equally between hook and line and net fishing. Spearfishing occurs both during the day and at night with battery-powered torches. Night spearfishing is very effective, providing high yields per fishing trip. It accounts for about $29 \%$ of lagoon fish production in the Windward Islands (which include Moorea) as compared to $18 \%$ in the Leeward Islands (SPE, 2007). Night spearfishing is very selective but can lead to local overexploitation of stocks because most targeted species $(80 \%)$ are non-migratory and tend to be confined to a specific habitat during the night (Lecaillon et al., 2000). Line fishing is done directly from the coastline or from small vessels 
TABLE 1 | Classification and characteristics of fishers on Moorea.

\begin{tabular}{|c|c|c|}
\hline Commercial fisher & Subsistence fisher & Recreational fisher \\
\hline Two to five fishing trips per week & One to three trips per week & One to four trips per month \\
\hline Sells catch & Some of the catch is sold and some is kept for home consumption & Catch is for home consumption \\
\hline Fishing is the main source of income for the year & Fishing is a supplementary form of income & Fishing is primarily a recreational activity \\
\hline
\end{tabular}

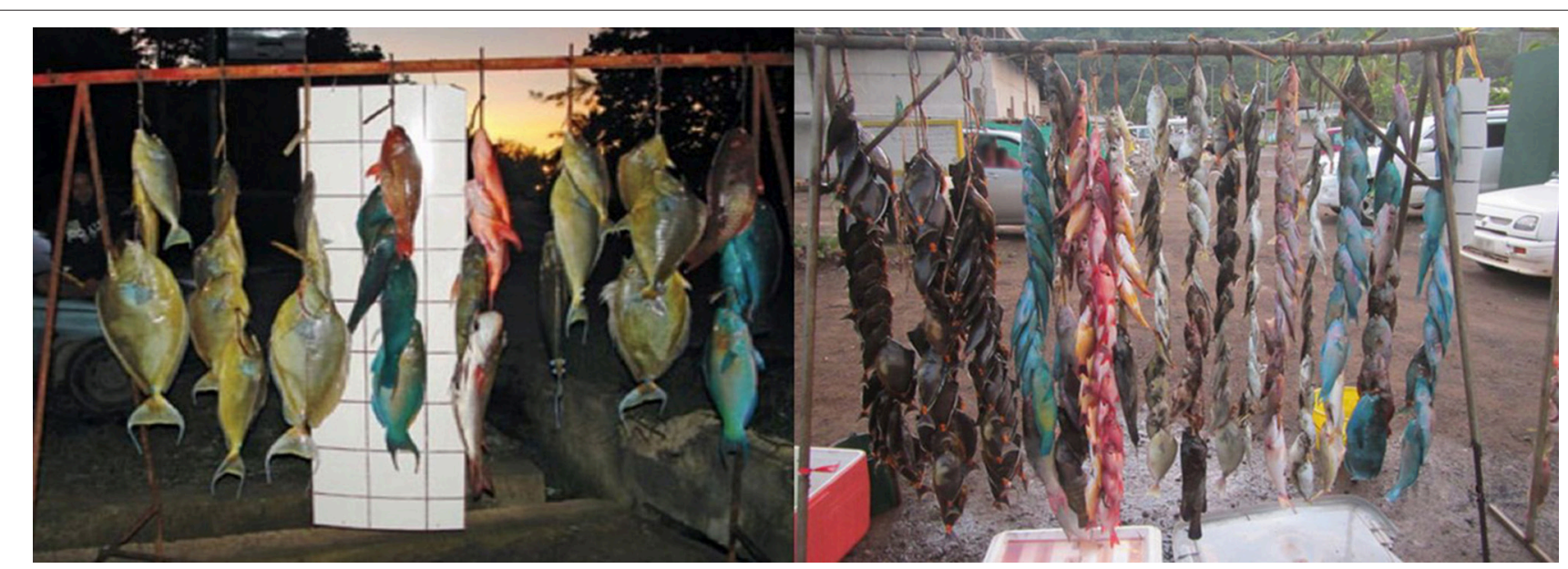

FIGURE 1 | Reef fish sold along the roadside on Moorea. Boards in background are used by scientists to estimate sizes (Images: R. Madi Moussa).

powered by oars or 2-25 hp outboard motors. The different line fishing techniques include trolling, bottom longlining, fishing with artificial lures, using lines with one or more hooks, and fishing with natural and live bait. Nets can take a wide variety of forms: gillnet fishing; beach seine net fishing (used seasonally on bay floors to catch bigeye scad, Selar crumenophthalmus); funnel net fishing that includes a wire net that targets parrotfish, trevallies, surgeonfish, and goatfish; and cast nets and scoop nets, which are used to catch flying fish. Fish traps are widely used in the Tuamotu and Leeward Islands, where they can account for $90 \%$ of catches (Galzin et al., 1989), but are not used in Moorea's lagoon.

\section{YIELD ESTIMATES}

A variety of studies in the past three decades have attempted to assess fish production (Galzin, 1985) or reef fishery yields (Aubanel, 1993a; Yonger, 2002; Brenier et al., 2014) on Moorea (Table 3). As in other coral island settings, quantifying reef fisheries yield has proven to be a particularly difficult exercise for many reasons. Fishing is often done at night (with or without a boat), is widely dispersed, uses many different types of gear, and landings and sales do not take place at specific sites but rather anywhere along the coast, often on private stretches of coastline (Figure 1). Research methodologies used between the times of Galzin (1985) and Brenier (2009) have also evolved considerably. Over a period of three decades, five different studies attempted to evaluate Moorea's lagoon fishery yield, and only two studies used the same methodology (Aubanel, 1993a; Vieux, 2002), leading to a wide range of production estimates for Moorea's coral reefs. Yield estimates based on catch data provide relatively low figures (from 0.7 to $2.2 \mathrm{t} \mathrm{km}^{-2}$ year ${ }^{-1}$ ), while, by contrast, data from consumption surveys or participatory surveys estimate fishing yields an order of magnitude higher (from 20 to $25 \mathrm{t} \mathrm{km}^{-2}$ year $\left.^{-1}\right)$.

\section{Monitoring Catches, Landings, and Sales}

Built in 1987, the Paopao market was once the single official point of sales where all fishers from the north side of the island were supposed to sell their fish. The centralized fish market was the result of a regulation that prohibited the sale of fish at roadside stands, although compliance with the law was low and eventually the Paopao market ceased to operate (Aubanel, 1993a). Galzin et al. (1989) estimated catches based on the tax the township levied on the fish sold at the Paopao market. Aubanel (1993a) estimated production and total catch based on fish sold both at roadside stands and at the Paopao market. These estimates were made by counting tuis, a string from which a collection of fish are hung, often of different species and sizes, and the unit by which fish are offered for sale (Figure 1). Vieux (2002) used the same protocol counting only roadside tuis (the market was closed by that time) to assess potential changes in total catch.

There were some methodological weaknesses of these assessments that most likely led them to underestimate fishery production. The tax-based approach (Galzin et al., 1989) did not account for non-market based sales (roadside sales and direct sales based on contracts), that were estimated afterwards to 
TABLE 2 | Relative abundance (percent) of important fished taxa sold by the roadside on Moorea since 1991.

\begin{tabular}{|c|c|c|c|c|c|c|c|c|}
\hline $\begin{array}{l}\text { Tahitian } \\
\text { name }\end{array}$ & Scientific name & $\begin{array}{l}1991 \\
\text { (Oct) }\end{array}$ & $\begin{array}{l}1992 \\
\text { (Mar) }\end{array}$ & $\begin{array}{c}2002 \\
\text { (June-July) }\end{array}$ & $\begin{array}{c}2007 \\
\text { (Jan-Sept) }\end{array}$ & $\begin{array}{c}2008 \\
\text { (Jan-Feb) }\end{array}$ & $\begin{array}{c}2012 \\
\text { (Jan-Mar) }\end{array}$ & $\begin{array}{c}\text { 2014-2015 } \\
\text { (June-May) }\end{array}$ \\
\hline Marava & Siganus argenteus & 20 & 10 & 4 & 4 & 2 & 2 & 4 \\
\hline Vete & Mulloidichthys vanicolensis & 16 & 10 & 2 & 2 & 1 & 1 & 0 \\
\hline Pahoro/Paati & $\begin{array}{l}\text { Scarus spp. or Chlorurus } \\
\text { spp. }\end{array}$ & 26 & 19 & 10 & 26 & 17 & 33 & 41 \\
\hline Ume & Naso unicornis & 8 & 20 & 13 & 31 & 33 & 5 & 4 \\
\hline Ume Tarai & Naso lituratus & 1 & 14 & 23 & 7 & 10 & 4 & 1 \\
\hline lihi & Myripristis spp. & NA & NA & 22 & 7 & 8 & 10 & 11 \\
\hline Other & Other & 29 & 28 & 26 & 24 & 28 & 45 & 39 \\
\hline
\end{tabular}

Data from: Galzin et al., 1989; Aubanel, 1993b; Vieux, 2002; Yonger, 2002; Brenier, 2009; Kronen et al., $2009 ;$ Madi Moussa, 2010.

TABLE 3 | Yield estimates per surface area unit by type of survey.

\begin{tabular}{|c|c|c|}
\hline Yield (t km-2 year $^{-1}$ ) & Type of data & Source \\
\hline 24.5 & Participatory surveys & Brenier, 2009 \\
\hline 28.14 & Socioeconomic surveys & Kronen et al., 2009 \\
\hline 22.9 & Direct consumption surveys & Yonger, 2002 \\
\hline $1.01-2.2$ & Fish sold on roadside & Vieux, 2002 \\
\hline $0.7-1.4$ & Fish sold on roadside & Aubanel, 1993a \\
\hline $1.2-1.4$ & Extrapolation of fishing data & Galzin et al., 1989 \\
\hline
\end{tabular}

be about $60 \%$ of the total catch (Vieux, 2002). Yield estimates based solely on roadside surveys (Aubanel, 1993b; Vieux, 2002) were most likely underestimated for the same reasons. However, and although done 10 years apart, those two assessments based on roadside surveys led to similar yield figures. Surprisingly, the tax-based study done 10 and 20 years earlier, respectively, led to estimates in the same range, suggesting that the market oriented reef catches were similar for the various fishing/selling categories. Although the spatially dispersed nature of landings makes quantifying fish catches difficult, monitoring roadside sales can be an excellent way of discerning spatial patterns of fishing pressure (fish are typically sold in roadside stands near to where the fish were caught) as well as the species and sizes of the fish sold (Figure 1; Madi Moussa, 2010).

\section{Consumption Surveys}

An analysis of seafood consumption can be a good alternative for indirectly assessing fishery production (Paddon, 1997; Gilbert, 2006; Labrosse et al., 2006). This method requires a welldefined study area with low quantities of imported or exported reef and lagoon fish. On Moorea, catch exports are limited to recreational fishers who come from Tahiti on the weekends and the importation of fish is negligible, with only small amounts of pelagic fish from Tahiti or the Tuamotu Islands being brought to the island (Leenhardt, 2009; Brenier et al., 2014). On Moorea, annual consumption is nearly $110 \mathrm{~kg}$ per inhabitant (Yonger, 2002), far above the $23 \mathrm{~kg}$ per inhabitant that is the average annual consumption for the Pacific Islands region (Labrosse et al., 2006; Kronen et al., 2010). The gap between estimates in Moorea and other Pacific Island countries is intriguing and encourages consideration of possible methodological biases. Studies either sampled 5\% of Moorea's household population (Yonger, 2002) or concentrated on a village and sampled $12 \%$ of its households (Kronen et al., 2010). However these two studies led to similar estimates. We believe a potential source of discrepancy with other similar studies in the region may be due to the fact that residents of Moorea consider leftovers to be a new individual meal (Gilbert, 2006). The one-off nature of the surveys also creates considerable uncertainty in the annual estimates, which were extrapolated from average weekly estimates. The methodology also assumed that eating habits and fishery production remain stable over time (Gilbert, 2006). Fish sizes were generally estimated with gauges, while size and weight conversions were calculated using biometric ratios. Size and weight ratios were not always calculated in a precise manner. In fact, length-weight relationships did not exist for the species studied, so relationships for similar species were used (Gilbert, 2006). Although the information collected from households was quantitative it involved substantial uncertainty because it relied on the short-term memory of the person interviewed and his or her ability to convert an image or a memory into a physical size (Gilbert, 2006).

Despite the drawbacks mentioned above, indirect studies based on household seafood consumption surveys offer a good alternative for studying fishery production in small-scale fisheries. In contrast to methods based on landings and sales monitoring, household consumption surveys take into account the catches of all types of fishers, including recreational fishers. They also have been conducted more frequently over the past few years (Yonger, 2002; Lagadec, 2003; Léopold et al., 2004; Kuster et al., 2006).

\section{Participatory Methods}

Participatory monitoring of reef fisheries through household surveys can be designed to collect data on consumption and fishing activities from large sample groups and can produce reliable data (Au et al., 2000; Nicholson et al., 2002). On Moorea, fishery production was estimated using surveys by schoolchildren (Brenier, 2009). Surveys consisted of questionnaires designed to gather general information (i) on the household's general fishing activities and fish consumption (including how often 
fish was eaten, origin of the fish eaten, number of boats and fishers in the household) and (ii) on the number of fishing trips of one fisher in the household over a 2-week period (to cover one spring tide period and one neap tide period) along with (iii) the names, sizes and number of fish eaten at meals over the previous 3 days. These surveys involved $4.4 \%$ of total household population and the questionnaire return rate was $68 \%$. The fisher population was estimated at 77 fishers per $\mathrm{km}^{2}$, with $1916 \pm 530$ motorboats and $481 \pm 68$ fishing trips per $\mathrm{km}^{2}$ each month (Brenier, 2009). If this calculated fishing pressure is accurate, it is quite high considering that 5 fishers per $\mathrm{km}^{2}$ is the upper limit at which coral reef resources can be safely exploited (McClanahan et al., 2002).

\section{PERCEPTIONS OF STOCK STATUS}

Perception surveys can also serve as a good indicator of fish stock status. On Moorea, perception surveys show mixed results with some indicating that Moorea has experienced a decline in the abundance and size of target fish species, increased scarcity of giant clams, decreased live coral cover, and increased cover of macroalgae (Brenier, 2009), while others suggest heterogeneity in perceptions between communities, with respondents from Afareaitu reporting more marine resource degradation than in southern Haapiti and Papetoai. Over the past decade, fishers in most districts report that they are still catching as many fish, yet most agree that their fishing effort has increased (Leenhardt, 2009), although there is some variation between districts. The varied perceptions about the health of fished stocks emphasize the difficulty of using such metrics to infer stock status. Responses are consistent with reefs that are either fully exploited or somewhat overexploited but show no evidence of collapse despite the heavy use.

\section{DISCUSSION}

Coral reef fisheries are multifaceted, and when fishers can fish for pleasure, identity, to eat or to sell, yields are very difficult to assess and large uncertainty is common. For instance, in Moorea's reef fisheries, there is considerable uncertainty on the magnitude of the catch or even the status of the stocks being fished. Over a period of 30 years, several studies have attempted to assess fishery production in Moorea's reefs, with nearly every study using a different methodology. Two approaches have yielded an order of magnitude gap between the estimates: $\sim 2 \mathrm{t} \mathrm{km}^{-2}$ year ${ }^{-1}$ using catch-monitoring methods vs. $\sim 24 \mathrm{t} \mathrm{km}^{-2}$ year $^{-1}$ using consumption or participatory socioeconomic consumer surveys (Table 2). Market surveys are unable to capture many kinds of fishing activity (e.g., recreational fishing, fishing for household consumption, and contract fishing for private clients), so we expect that methods based on these surveys would underestimate fishery production. Methods involving socioeconomic surveys might potentially give more accurate fishery production estimates as they apply to all fish consumed on the island regardless of source, but they rely on recollections of fish recently consumed, rather than on direct observation, introducing other forms of uncertainty.

Similar to many small-scale coral reef fisheries, fishery activities in Moorea's lagoon are quite challenging to monitor and quantify because they vary greatly and are quite dispersed. While estimates of actual production are uncertain, the potential sustainable productivity of Moorea's lagoon fisheries is completely unknown. In fact, there may not be any reliable guidelines for the sustainable yield of many of these fish species, as their biomasses have been shown to change by a factor of five or more over time scales as short as a few years during rapid ecological transitions (Adam et al., 2011, 2014). At present, these variations in biomass are not predictable some are driven by pulse disturbance events (Adam et al., 2014), and there is no infrastructure for monitoring stock status that would permit dynamic estimation of sustainable yield.

Adding to the complexity is the fact that Moorea's reefs have been subjected to several large perturbations in the past four decades, including in 2008-2010 (Adjeroud et al., 2009; Trapon et al., 2011; Adam et al., 2014; Lamy et al., 2015, 2016). In all cases, the coral community on the fore reef displayed high resilience to perturbation -returning to predisturbed coral cover $(\sim 40-50 \%)$ within about a decade without undergoing a shift to high cover of macroalgae (Adjeroud et al., 2009; Trapon et al., 2011; Adam et al., 2014; Lamy et al., 2016) due in large part to herbivorous fishes preventing the establishment of macroalgae on the fore reef (Adam et al., 2011, 2014). Following the recent disturbances, the relative abundances and biomass of species targeted by Moorea's fishers changed, with several key groups of herbivores experiencing large increases.

The complexity of Moorea's coral reef fishery, in many ways, is representative of other small-scale coral reef fisheries around the world. A wide diversity of fish is caught with at least five major gear types and fishing occurs during day or night without any regular schedules or formalized protocols. Moorea's fishery, however, becomes more place-specific when we consider the socio-economic context and the motivations that underlie why people fish. Unlike many other small-scale coral reef fisheries in the Pacific and around the world, French Polynesia is a relatively rich country. For this reason Moorea households are not dependent on marine resources for protein or their livelihoods to the same extent as in poorer countries where necessity motivates the harvesting of marine resources. For this reason, only a small percentage of Moorea households identify fishing as their primary source of income or livelihood. Instead, fishing is vitally important for its non-material benefits. The primary motivation for fishing on Moorea is related to an important cultural factor: eating fresh reef fish. For Moorea's inhabitants the consumption of fresh reef fish is as fundamental to their identity as speaking the Tahitian language. It is pivotal to culturally important events such as Church gatherings, birthdays, Sunday feasts, and other events and continues to dominate the local diet. For these reasons, the three categories of fishersubsistence, commercial, and recreational-that are frequently cited in the literature on small-scale fisheries do not fully capture 
the nature of fishing on Moorea. Culturally motivated fishing, although most similar to recreational fishing, translates into fishing behavior that cannot easily be analyzed within a costbenefit or profit maximization model where the economic value generated by the activity forms the core of the analysis. To more deeply comprehend fishing on Moorea the non-material benefits related to the Polynesian lifestyle and identity must be considered.

Given the social and ecological complexity of Moorea's lagoon fisheries, any attempt to understand their dynamics will likely require integrated methods that consider both systems simultaneously. More integrated fieldwork is required to better evaluate the sustainability of the existing fisheries, in which social science techniques are paired with ecological field surveys to understand how fishing behavior depends on ecological state, livelihood opportunities, non-material benefits, cultural cohesion, and personal identity.

\section{CONCLUSIONS}

Understanding Moorea's lagoon fisheries is a major challenge, but also an opportunity. In important ways, Moorea may provide a window into the future of many other islands in the Pacific. Although the influence of globalization and economic development will inevitably vary across the Pacific, many Pacific Island nations are undergoing socio-cultural and economic changes similar to Moorea in that their population densities are increasing, their economies are modernizing and becoming more linked to global flows of trade and travel, and their fisheries are no longer managed through traditional marine tenure practices. If other island nations in the Pacific undergo similar changes, their small-scale fisheries may increasingly come to resemble Moorea's, where fishers are less dependent on the marine environment for subsistence or income and more motivated by non-material factors that sustain personal and cultural identity. Despite these changes on Moorea, its reefs are still superficially healthy with high coral cover and abundant fish. We acknowledge Moorea is unique in that it is economically and geopolitically linked to France, but studying Moorea's system might yield insight into how the processes of globalization can be effectively and sustainably navigated both ecologically and socially in similar contexts in Polynesia such as Hawaii.

\section{AUTHOR CONTRIBUTIONS}

PL wrote the first draft and all authors contributed substantially to revisions.

\section{ACKNOWLEDGMENTS}

We thank Mark Strother Ashley Bunnell, Terava Atgar, and René Galzin for their help in data collection, and CRIOBE staff and Hinano Murphy for facilitating the project and securing research permits. Two anonymous reviewers made constructive comments on an earlier version of this manuscript. This work was supported by the Fondation de France, The Programme Doctoral International: Modélisation des Systèmes Complexes (PDIMSC) from Université Pierre et Marie Curie, the Agence Nationale de la Recherche (ANR-14-CE03-0001-01), the National Science Foundation (NSF OCE 1325652, OCE 1325554, and OCE 1236905).

\section{REFERENCES}

Adam, T. C., Brooks, A. J., Holbrook, S. J., Schmitt, R. J., Washburn, L., and Bernardi, G. (2014). How will coral reef fish communities respond to climatedriven disturbances? Insight from landscape-scale perturbations. Oecologia 176, 285-296. doi: 10.1007/s00442-014-3011-x

Adam, T. C., Schmitt, R. J., Holbrook, S. J., Brooks, A. J., Edmunds, P. J., Carpenter, R. C., et al. (2011). Herbivory, connectivity, and ecosystem resilience: response of a coral reef to a large-scale perturbation. PLOS ONE 6:e23717. doi: 10.1371/journal.pone.0023717

Adjeroud, M., Michonneau, F., Edmunds, P. J., Chancerelle, Y., Lison de Loma, T., Penin, L., et al., (2009). Recurrent disturbances, recovery trajectories, and resilience of coral assemblages on a South Central Pacific reef. Coral Reefs 28, 775-780. doi: 10.1007/s00338-009-0515-7

Au, J., Bagchi, P., Chen, B., Martinez, R., Dudley, S. A., and Sorger, G. J. (2000). Methodology for public monitoring of total coliforms, Escherichia coli and toxicity in waterways by Canadian high school students. J. Environ. Manage. 58, 213-230. doi: 10.1006/jema.2000.0323

Aubanel, A. (1993a). Évaluation socio-économique de la pêche en milieu corallien dans l'île de Moorea (Polynésie française): persistance d'une consommation locale traditionnelle hors du développement touristique. J. Soc. Océan. 96, $49-62$.

Aubanel, A. (1993b). Valeurs socio-économiques du milieu corallien récifal et de ses ressources: application à une île océanique du Pacifique sud. Moorea: Archipel de la société; University of Bordeaux 3.

Aubanel, A., Salvat, B., and Féral, F. (2013). Analyse du Role des Scientifiques et de la Place des Connaissances Scientifiques dans L'elaboration et la Mise en œuvre du

Plan de Gestion de L'espace Maritime (PGEM) de Moorea et de sa Gouvernance. CRIOBE, BEST CORAL Reports, Communication for Policy.

Baudchon, G., De Clercq, H., and Supera, L. (Eds) (2008). Les Défis de la Croissance Calédonienne. Agence Française de Développement, Institut de la Statistique et des Etudes Economiques, Institut d'Emission d'Outre-Mer.

Bell, J. D., and Galzin, R. (1984). Influence of live coral cover on coral-reef fish communities. Mar. Ecol. Prog. Ser. 15, 265-274. doi: 10.3354/meps0 15265

Brenier, A. (2009). Pertinence des Approches Participatives Pour le Suivi Écosystémique des Pêcheries Récifales. Ph.D., Université Paris Pierre et Marie Curie and Université de Tuléar.

Brenier, A., Mahafina, J., Galzin, R., and Ferraris, J. (2014). Approches participatives: une solution pour le suivi des pêcheries récifales? Nat. Sci. Soc. 21, 293-306. doi: 10.1051/nss/2013109

Brewer, D. T., Morello, E. B., Griffiths, S., Fry, G., Heales, D., Apte, S. C., et al. (2012). Impacts of gold mine waste disposal on a tropical pelagic ecosystem. Mar. Pollut. Bull. 64, 2790-2806. doi: 10.1016/j.marpolbul.2012.09.009

Bruno, J. F., Sweatman, H., Precht, W. F., Selig, E. R., and Schutte, V. G. W. (2009). Assessing evidence of phase shifts from coral to macroalgal dominance on coral reefs. Ecology 90, 1478-1484. doi: 10.1890/08-1781.1

Cinner, J. E., Daw, T., and McClanahan, T. R. (2009). Socioeconomic factors that affect artisanal fishers' readiness to exit a declining fishery. Conserv. Biol. 23, 124-130. doi: 10.1111/j.1523-1739.2008.01041.x

Cinner, J. E. (2014). Coral reef livelihoods. Curr. Opin. Environ. Sustain. 6, 65-71. doi: 10.1016/j.cosust.2013.11.025

Cinner, J., Fuentes, M., and Randriamahazo, H. (2009). Exploring social resilience in Madagascar's marine protected areas. Ecol. Soc. 14, 41-41. 
Done, T. J., Dayton, P. K., Dayton, A. E., and Steger, R. (1991). Regional and local variability in recovery of shallow coral communities: Moorea, French Polynesia and central Great Barrier Reef. Coral Reefs 9, 183-192. doi: 10.1007/bf00290420

Galzin, R. (1985). Écologie des poissons rêcifaux de Polynésie française. Cybium 9, 403-407.

Galzin, R., Lecchini, D., Lison de Loma, T., Moritz, C., Parravicini, V., and Siu, G. (2016). Long term monitoring of coral and fish assemblages (1983-2014) in Tiahura reefs, Moorea, French Polynesia. Cybium 40, 31-41. Available online at: http://sfi.mnhn.fr/cybium/numeros/2016/401/sommaire401.html

Galzin, R., Morize, E., Stein, A., and Conte, E. (1989). Dégradations Naturelles et/ou Anthropiques en Zones Cótiêres Intertropicales et Répercussions Possibles sur Léconomie des Pêches: Le Cas Des Récifs Coralliens. Action CORDET, Rapport Antenne EPHE/Muséum, RA 32.

Gaspar, C., and Bambridge, T. (2008). Territorialités et aires marines protégées à Moorea (Polynésie française). J. Soc. Océan 126-127, 231-246. doi: $10.4000 /$ jso. 2462

Gilbert, A. (2006). Prêcision et Biais des Estimations de la Consommation de Poissons par Enquêtes Auprés des Mênages. Cas de la commune de Haapiti (Moorea) Polynêsie française. UR-CoReUs, CRISP.

Henningham, S. (1992). France and the South Pacific: A Contemporary History. Honolulu, HI: University of Hawaii Press.

Hobbs, R. J., Arico, S., Aronson, J., Baron, J. S., Bridgewater, P., Cramer, V., et al. (2006). Novel ecosystems: theoretical and management aspects of the new ecological world order. Glob. Ecol. Biogeogr. 15, 1-7. doi: 10.1111/j.1466822X.2006.00212.x

Hughes, T. P. (1994). Catastrophes, phase shifts, and large-scale degradation of a Caribbean coral reef. Science 265, 1547-1551. doi: 10.1126/science.265.5178.1547

Hughes, T. P., Baird, A. H., Bellwood, D. R., Card, M., Connolly, S. R., Folke, C., et al. (2003). Climate change, human impacts, and the resilience of coral reefs. Science 301, 929-933. doi: 10.1126/science.1085046

Hughes, T. P., Bellwood, D. R., Folke, C., Steneck, R. S., and Wilson, J. (2005). New paradigms for supporting the resilience of marine ecosystems. Trends Ecol. Evol. 20, 380-386. doi: 10.1016/j.tree.2005.03.022

Hughes, T. P., Graham, N. A. J., Jackson, J. B. C., Mumby, P. J., and Steneck, R. S. (2010). Rising to the challenge of sustaining coral reef resilience. Trends Ecol. Evol. 25, 633-642. doi: 10.1016/j.tree.2010.07.011

ISPF (2001). Enquête de Fréquentation dans la Petite Hôtellerie Familiale (EFPHF). Papeete: Institut de la Statistique de la Polynésie Française.

ISPF (2013). Populaiton Légale du Descencement de la Populaiton de 2012 en Polynésie Française. Papeete: Institut de la Statistique de la Polynésie Française.

Jackson, J. B. C. (1992). Pleistocene perspectives on coral reef community structure. Am. Zool. 32, 719-731. doi: 10.2307/3883652

Jacquet, J., and Pauly, D. (2008). Funding priorities: big barriers to small-scale fisheries. Conserv. Biol. 22, 832-835. doi: 10.1111/j.1523-1739.2008.00978.x

Jennings, S., and Kaiser, M. J. (1998). The effects of fishing on marine ecosystems. Adv. Mar. Biol. 34, 201-352. doi: 10.1016/s0065-2881(08)60212-6

Johnson, A. E., Cinner, J. E., Hardt, M. J., Jacquet, J., McClanahan, T. R., and Sanchirico, J. N. (2013). Trends, current understanding and future research priorities for artisanal coral reef fisheries research. Fish Fish. 14, 281-292. doi: 10.1111/j.1467-2979.2012.00468.x

Kronen, M., Friedman, K., Pinca, S., Chapman, L., Awiva, R., Pakoa, K., et al. (2009). Programme Régional de Développement des Pêches Océaniques et Côtières. Polynésie Française, Rapport de Pays. Secrétariat Général de la Communauté du Pacifique.

Kronen, M., Vunisea, A., Magron, F., and McArdle, B. (2010). Socio-economic drivers and indicators for artisanal coastal fisheries in Pacific island countries and territories and their use for fisheries management strategies. Mar. Policy 34, 1135-1143. doi: 10.1016/j.marpol.2010.03.013

Kuster, C., Vuki, V. C., and Zann, L. P. (2006). Validation of the accuracy of household reporting of subsistence fishing catch and effort: a Fijian case study. Fish. Manag. Ecol. 13, 177-184. doi: 10.1111/j.1365-2400.2006. 00492.x

Labrosse, P., Ferraris, J., and Letourneur, Y. (2006). Assessing the sustainability of subsistence fisheries in the Pacific: the use of data on fish consumption. Ocean Coast. Manag. 49, 203-221. doi: 10.1016/j.ocecoaman.2006. 02.006
Lagadec, X. (2003). Etude de L'évolution Halieutique d'un Atoll de Polynésie Française: Description du systéme Pêche de L'atoll de Tikehau Par le Biais D'enquêtes de Consommation, Évolution sur 20 Ans. ENSAR.

Lamy, T., Galzin, R., Kulbick, M., Lison de Loma, T., and Claudet, J. (2016). Three decades of recurrent declines and recoveries in corals belie ongoing change in fish assemblages. Coral Reefs 35, 293-302. doi: 10.1007/s00338-0151371-2

Lamy, T., Legendre, P., Chancerelle, Y., Siu, G., and Claudet, J. (2015). Understanding the spatio-temporal response of coral reef fish communities to natural disturbances: insights from beta-diversity decomposition. PLoS ONE 10:e0138696. doi: 10.1371/journal.pone.0138696

Lecaillon, G., Dufour, V., and Lenfant, P. (2000). Les pêcheries dans les rêcifs coralliens. Ocêanis 26, 543-569.

Leenhardt, P. (2009). Influence de la mise en place d'Aires Marines Protégées (AMP) Sur la Pêche Lagonaire: Validation d'un Modèle par Réseaux Bayésiens Appliqué au cas D'étude de Moorea (Polynésie Française). Agrocampus Ouest.

Léopold, M., Ferraris, J., and Labrosse, P. (2004). Assessment of the reliability of fish consumption as an indicator of reef fish catches in small Pacific islands: the example of Ouvea Island in New Caledonia. Aquat. Living Resour. 17, 119-127. doi: 10.1051/alr: 2004020

Madi Moussa, R. (2010). Estimation de la taille des poissons lagonaires vendus sous la forme de tui en bord de route sur l'île de Moorea (Polynésie française) par analyse de clichés numériques. Cybium 34, 73-82.

McClanahan, T., Polunin, N., and Done, T. (2002). Ecological states and the resilience of coral reefs. Conserv. Ecol. 6, 18. Available online at: http://www. consecol.org/vol6/iss $2 /$ art18

Mumby, P. J., and Steneck, R. S. (2008). Coral reef management and conservation in light of rapidly evolving ecological paradigms. Trends Ecol. Evol. 23, 555-563. doi: $10.1016 /$ j.tree.2008.06.011

Newton, K., Côté, I. M., Pilling, G. M., Jennings, S., and Dulvy, N. K. (2007). Current and future sustainability of island coral reef fisheries. Curr. Biol. 17, 655-658. doi: 10.1016/j.cub.2007.02.054

Nicholson, E., Ryan, J., and Hodgkin, D. (2002). Community data-where does the value lie? Assessing confidence limits of community collected water quality data. Water Sci. Technol. 45, 193-200.

Oliver, D. (1974). Ancient Tahitian Society. Honolulu: University of Hawaii Press.

Paddon, J. R. (1997). Fishing Pressure on Demersal Lagoon Fish in the North Province of New Caledonia, South Pacific: Evaluation, Impact on Stock Assessment and Implications for Management. Master of Arts thesis, RSMAS, University of Miami.

Pandolfi, J. M., and Jackson, J. B. (2006). Ecological persistence interrupted in Caribbean coral reefs. Ecol. Lett. 9, 818-826. doi: 10.1111/j.14610248.2006.00933.x

Pascal, N., and LePort, G. (2015). Valeur Monétaire Des Écosystèmes Coralliens Et Associés De Moorea. Criobe, Best Coral Reports, Economic Valuations.

Pauly, D., and Chua, T. E. (1988). The overfishing of marine resources: socioeconomic background in Southeast Asia. Ambio 17, 200-206.

Rogers, C. S., and Miller, J. (2006). Permanent "phase shifts" or reversible declines in coral cover? Lack of recovery of two coral reefs in St. John, US Virgin Islands. Mar. Ecol. Progr. Ser. 306, 103-114. doi: 10.3354/meps3 06103

Russ, G., and Alcala, A. C. (1989). Effects of intense fishing pressure on an assemblage of coral reef fishes. Mar. Ecol. Prog. Ser. 56, 13-27. doi: $10.3354 /$ meps 056013

Salvat, B., and Pailhe, C. (2002). "Islands and Coral Reefs, population and culture, economy and tourism: world view and a case study of French Polynesia," in Tourism, Biodiversity and Informaiton, eds F. di Castri and V. Balaji. (Leiden: Backhuys Publishers), 213-231.

Shulman, M. J., and Robertson, D. R. (1996). Changes in the coral reefs of San Blas, Caribbean Panama: 1983 to 1990. Coral Reefs 15, 231-236. doi: $10.1007 /$ bf01787457

SPE (2007). Synthèse des Données de la Pêche Professionnelle et de L'Aquaculture. Papeete.

Teh, L. S., Teh, L. C., and Sumaila, U. R. (2013). A global estimate of the number of coral reef fishers. PLoS ONE 8:e65397. doi: 10.1371/journal.pone.0065397 
Trapon, M. L., Pratchett, M. S., and Penin, L. (2011). Comparative effects of different disturbances in coral reef habitats in Moorea, French Polynesia. J. Mar. Biol. 2011, 1-11. doi: 10.1155/2011/ 807625

Vieux, C. (2002). La Peche Lagonaire á Moorea (Polynésie française): Évolution Quantitative et Socio- Économique Depuis 1992. Papeete: CRIOBE.

Walker, B. L. E. (2001). “Mapping Moorea's lagoon: conflicts over marine protected areas in French Polynesia," in Tradition and Globalisation: Critical Issues for the Accommodation of CPRs in the Pacific Region, Inaugural Pacific Regional Meeting of the International Association for the Study of Common Property (IASCP) (Brisbane, QLD), 1-23.

Walker, B. L. E., and Robinson, M. (2009). Economic development, marine protected areas and gendered access to fishing resources in a Polynesian lagoon. Gender Place Cult. 16, 467-484. doi: 10.1080/096636909030 03983
Yonger, M. (2002). Approche de la Pêcherie Récifo-Lagonaire de Moorea (Polynésie française): Évaluation de la Production Halieutique et de la Population de Pêcheurs. Rennes: ENSA.

Conflict of Interest Statement: The authors declare that the research was conducted in the absence of any commercial or financial relationships that could be construed as a potential conflict of interest.

Copyright (c) 2016 Leenhardt, Lauer, Madi Moussa, Holbrook, Rassweiler, Schmitt and Claudet. This is an open-access article distributed under the terms of the Creative Commons Attribution License (CC BY). The use, distribution or reproduction in other forums is permitted, provided the original author(s) or licensor are credited and that the original publication in this journal is cited, in accordance with accepted academic practice. No use, distribution or reproduction is permitted which does not comply with these terms. 